\title{
Aerobic Rice for Nutrient and Water Use Efficiency in Lateritic Soils of Kerala
}

\author{
Geetha P.* and P. Sureshkumar
}

Radiotracer laboratory, College of Horticulture, Kerala Agricultural University, Vellanikkara, Thrissur, Kerala (680 656), India

\section{Corresponding Author}

Geetha P.

e-mail: geethapattath84@gmail.com

\section{Article History}

Article ID: 3 C0676

Received in $26^{\text {th }}$ October, 2017

Received in revised form $12^{\text {th }}$ September, 2018

Accepted in final form $18^{\text {th }}$ September, 2018

\begin{abstract}
Field experiments on aerobic and flooded systems of rice were conducted in lateritic soil to study the nutrient and water use efficiency in these systems.Three doses of lime (as per package of practices recommendations, KAU, as per $\Delta \mathrm{pH}$ and as per SMP buffer method) were imposed in plots of $20 \mathrm{~m}^{2}$ area in RBD with four replications. In situ measurement of $\mathrm{pH}$ and redox potential was done under both systems. The increase in $\mathrm{pH}$ and EC in both systems was in maintaining a linear relationship to the quantity of lime applied. The organic carbon content and $\mathrm{N}$ in plant were higher under aerobic environment. Available $\mathrm{P}$ and boron were highest under flooded system. Available Fe and hence its concentration in plant could be reduced by keeping the rhizosphere aerobic; enhanced the availability and uptake of $\mathrm{P}$, $\mathrm{K}$ and $\mathrm{Zn}$. Fresh root CEC as well as apparent free space were also found higher under aerobic system. Aerenchymatic tissue in the roots was observed only under flooded system. Root mass, shoot mass and root length at active tillering stage indicated that aerobic environment enhanced root and shoot growth when compared to flooded system. Number of tillers hill ${ }^{-1}$, number of panicles hill-1 and number of grains panicle ${ }^{-1}$ were higher under aerobic system. Grain yield and straw yield were also higher under aerobic system. The water requirement was reduced by $57 \%$ in aerobic rice.
\end{abstract}

Keywords: Lateritic soil, aerobic rice, flooded rice, nutrient efficiency

\section{Introduction}

Rice the global grain is the most important staple food crop in the world for nearly half of the world population (Mahabub and Narciso, 2004). Rice is grown at present in two main ecosystems under (1) flooded anaerobic and (2) well drained aerobic environments.

Under flooded system, reduction occurs within a few days due to absence of oxygen, resulting in enormous increase in concentration of ferrous $\left(\mathrm{Fe}^{2+}\right)$ ion (Fageria et al., 2008a). This definitely causes toxicity especially in tropical acidic soils which are rich in iron (Rout and Sahoo, 2015). Iron (Fe) toxicity is a widespread nutrient disorder of wetland rice grown in acid sulfate and lateritic soils of tropical humid regions (Saharawat, 2005). The $\mathrm{Fe}^{2+}$ in soil solution, when reaches the surface of the roots, partly oxidised to $\mathrm{Fe}^{3+}$ form and get deposited on the roots as insoluble oxides making them inactive; hindering ion absorption (Fageria and Baligar, 2003). Such roots slowly start decaying. Inactivation of roots due to deposition of iron oxides and production of new roots from immediate upper nodes along with new unproductive tillers are also observed in rice plants grown on such soils. This phenomenon physiologically reduces grain yield due to wastage of metabolic energy for production of unproductive tillers Geetha and Sureshkumar, 2006). The higher concentration of $\mathrm{Fe}^{2+}$ in the rhizosphere has antagonistic effects on the absorption of other essential elements such as P, K, Ca, Mg and Zn (Fageria et al., 2011), further accentuate to severe yield reduction (Fageriaet al., 2008 b). Thus, iron toxicity ultimately results in yield reduction to the tune of 12 to $100 \%$ (Saharawat, 2005). Under aerobic system, the rhizosphere soil is well aerated leading to oxidation, which, ultimately maintain iron in insoluble ferric $\left(\mathrm{Fe}^{3+}\right)$ form (Zuo and Zhang, 2011; Samaranayke et al., 2012). In acidic soil, liming also enhances precipitation of iron due to increase in $\mathrm{pH}$ (Fageria and Baligar, 2008). Thus, rice culture under aerobic environment can reduce iron toxicity, along with reduction in water use.

It is in this background, the present study, was undertaken with an objective of comparing the nutrient and water use efficiency of flooded and aerobic systems of rice cultivation in a lateritic soil of Kerala.

\section{Materials and Methods}

The present Field experiments on aerobic and flooded systems of rice were conducted in lateritic soilin farmer's field at Nellikkattiri during 2011-2012 (10. $7681507 \mathrm{~N}$ and 76.1584527 E). Thirumittakkode panchayat in Palakkad district Kerala state, India to meet the objectives in second crop season (August-September to December-January locally called as 
mundakan) with rice variety - Jyothi. to study the nutrient and water use efficiency in these systems. The initial soil samples (0-15 cm depth) from the experiment sites were collected and the parameters- $\mathrm{pH}, \mathrm{EC}$, organic carbon and available nutrient status viz.P, K, Ca, Mg, S, Fe, Cu, Mn, Zn and B were estimated using standard procedures. The physico-chemical properties of the soil collected from the experiment sites before the experiment are presented in Table 1.

Table 1: Physico-chemical properties of the soil of the experiment sites

\begin{tabular}{lcccc}
\hline Parameters & $\begin{array}{c}\text { Flood- } \\
\text { ed rice }\end{array}$ & Ratings & $\begin{array}{c}\text { Aero- } \\
\text { bic rice }\end{array}$ & Ratings \\
\hline pH & 4.9 & $\begin{array}{c}\text { Very strongly } \\
\text { acidic }\end{array}$ & 4.2 & $\begin{array}{c}\text { Extremely } \\
\text { acidic }\end{array}$ \\
EC dSm-1 & 0.01 & Normal & 0.05 & Normal \\
OC \% & 0.95 & Medium & 0.94 & Medium \\
Available nutrient status & Medium & 13.33 & Medium \\
\hline P kg ha-1 $^{-11.35}$ & Low & 113.3 & Low \\
$\mathrm{K} \mathrm{kg} \mathrm{ha-1}^{-1}$ & 51.07 & Deficient & 95.6 & Deficient \\
Ca mg kg-1 & 68.02 & Deficient & 6.2 & Deficient \\
Mg mg kg $^{-1}$ & 8.18 & Sufficient & 11.3 & Sufficient \\
S mg kg ${ }^{-1}$ & 14.39 & Sufficient & 56.8 & Sufficient \\
Fe mg kg-1 & 113.74 & Sufficient \\
Cu mg kg-1 & 6.10 & Sufficient & 9.6 & Sufficient \\
Mn mg kg-1 & 18.24 & Sufficient & 29.5 & Sufficient \\
Zn mg kg-1 & 2.80 & Sufficient & 1.7 & Sufficient \\
B mg kg-1 & 0.110 & Deficient & 0.07 & Deficient \\
\hline
\end{tabular}

The experiments under both the systems were conducted with three doses of lime and two doses of fertilizers. The lime treatments were (i) as per Package of Practices recommendations, KAU (600 kg ha-1) (KAU, 2011), (ii) as per $\triangle \mathrm{pH}$ (difference between required $\mathrm{pH}$ and measured $\mathrm{pH}$ ) and (iii) as per SMP buffer method (Shoemaker et al., 1961). The source of lime was $\mathrm{CaO}$ which was applied based on calcium carbonate equivalence. The fertilizer treatments were (i) as per Package of Practices recommendations, KAU (N, P, K 90:45:45 kg ha-1+FYM @ 5 t ha $\left.^{-1}\right)(K A U, 2011)$ and (ii) Package of Practices recommendations, KAU modified based on soil test values which include secondary and micro nutrients also. These treatments were imposed in plots of $20 \mathrm{~m}^{2}$ area in Randomized Block Design with four replications.

Under flooded system, application of lime and fertilizers were done based on analysis of wet samples as such (wet analysis). For this, the wet core soil samples were collected $(0-15 \mathrm{~cm}$ depth) from the field to a plastic cover and kept air tight maintaining the anaerobic environment. The moisture content of the soil samples were analysed immediately to express the results on dry weight basis in order to maintain the uniformity of the data. Under aerobic system of rice cultivation, soil samples collected were analysed after air drying.

Seedlings of 18 days were transplanted to the main plots at a spacing of $15 \times 10 \mathrm{~cm}^{2}$. A water level of $5 \mathrm{~cm}$ was maintained in the field till the harvest of the crop in case of the experiment on flooded rice. In experiment on aerobic rice, thesoil environment was made aerobic by decreasing the water level in the field after transplanting. Afterwards irrigation was provided for the crop at two to three days interval during evening hours.

The soil and plant samples were collected at three stages viz. at active tillering, panicle initiation and at harvest of the crop and analysed using standard procedures.Analysis of variance in RBD was made using MSTATC package.Pooled analysis of data on flooded and aerobic systems was carried out by the method suggested by Panse and Sukatme (1978). The general comparison of flooded and aerobic systems after pooled analysis of the data generated is discussed in the paper.

\subsection{In situ measurements of $\mathrm{pH}$ and redox potential}

In situ measurement of $\mathrm{pH}$, and redox potential was done under both systems of rice cultivation. Redox potential was measured from three different depths under flooded system $(15,30$ and $45 \mathrm{~cm})$ and from two different depths under aerobic system (30 and $45 \mathrm{~cm}$ ).

\section{Results and Discussion}

\subsection{In situ measurements of $\mathrm{pH}$ and redox potential}

The $\mathrm{pH}$ of the soils both under aerobic and flooded environment increased from initial status, 4.2 to 6.13 and 4.9 to 5.99 respectively. The $\mathrm{pH}$ increased immediately after application of lime, which was applied just before transplanting under both systems of rice cultivation. The rate of increase was in proportion to the quantity of lime applied under both systems. However, the rate was observed to be less under flooded system of rice. The $\mathrm{pH}$ attained the highest value of 8 at six weeks after transplanting in aerobic rice when lime was applied as per SMP buffer method. The corresponding $\mathrm{pH}$ under flooded system was 6.8 where the quantity of lime applied was $2.4 \mathrm{t} \mathrm{ha}^{-1}$.

Under aerobic system, the redox potential was negative at the start due to puddled environment, later transformed to positive values indicating the transformation of anaerobic environment to aerobic environment, which remained throughout the cropping season. Under flooded system, the redox potential was negative throughout the cropping season which is an indication of maintenance of anaerobic environment throughout the crop growth period. The reduction was more with the increase in depth (Figure 1).

\subsection{Comparison available nutrient status and plant content}

\subsubsection{Major nutrients}

The highest organic carbon content was recorded in aerobic rice cultivation at active tillering and panicle initiation (Table 


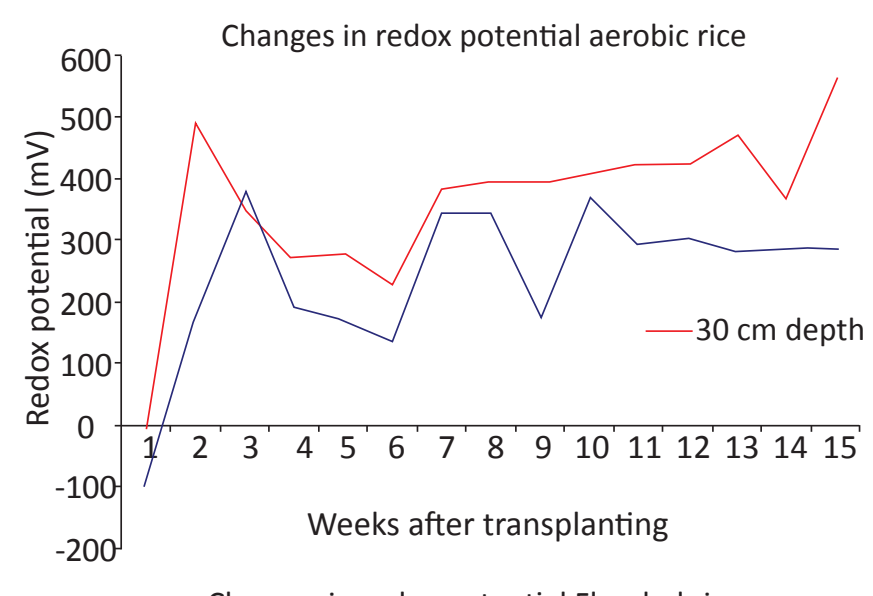

Changes in redox potential Flooded rice

- $15 \mathrm{~cm}$ depth flooded rice $-30 \mathrm{~cm}$ depth flooded rice - $45 \mathrm{~cm}$ depth flooded rice

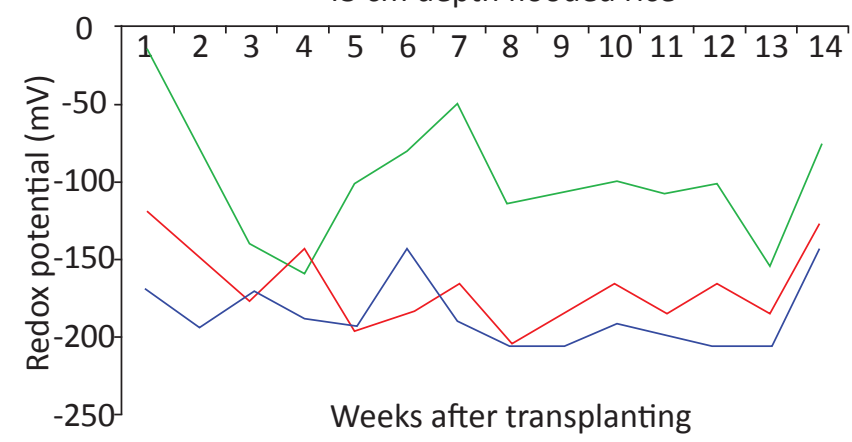

Figure 1: Variations in redox potential under aerobic and flooded systems at weekly interval

2) even though same quantity of organic manure was added under both systems $\left(5 \mathrm{t} \mathrm{ha}^{-1}\right)$ due to the quicker decomposition of applied manure in presence of lime. Further, at harvest, organic carbon found decreased under aerobic system (Sahrawat, 2012). The enhanced rate of decomposition of organic manure and release of $\mathrm{CO}_{2}$ must have depleted the organic carbon status quickly under aerobic system. Under flooded anaerobic environment, the decomposition and release of $\mathrm{CO}_{2}$ was at a slower rate resulted in maintaining organic carbon status near to the initial level. The OM status of soils under continuous rice (two or three crops per year) is either maintained or even increased compared with soils under upland rice,where a general decline in soil organic matter has been reported (Cheng et al., 2009). Further, the rate of decomposition of organic manure was found highest in lime applied treatments as per SMP buffer method, under both systems of rice cultivation(Figure 2). The enhanced rate of decomposition and release of nitrogen from aerobic system with minimal leaching losses resulted in more $\mathrm{N}$ content in plant (Table 3).

Aerobic system, recorded the lowest available $\mathrm{P}$ status at active tillering and panicle initiation due to precipitation/

Effect of lime on organic carbon \%

$\checkmark$ Lime (POP) aerobic rice $-\square-$ Lime $(\Delta \mathrm{pH})$ aerobic rice - - Lime (SMP) aerobic rice $-\varangle-$ Lime (POP) flooded rice $\rightarrow-$ Lime $(\triangle \mathrm{pH})$ flooded rice $\longrightarrow$-Lime $(\mathrm{SMP})$ flooded rice

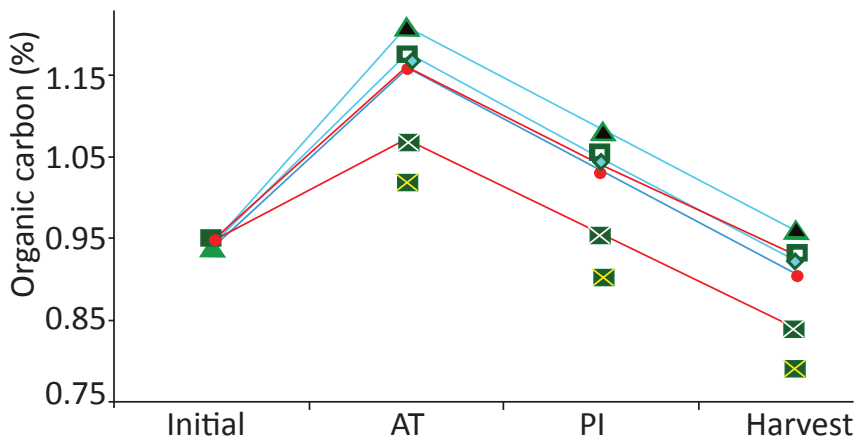

Figure 2: changes in organic carbon under aerobic an flooded systems

\begin{tabular}{|c|c|c|c|c|c|c|c|c|c|}
\hline \multirow[t]{2}{*}{ Parameters } & \multicolumn{2}{|c|}{ Active tillering } & \multirow{2}{*}{$\begin{array}{c}C D \\
(p=0.05)\end{array}$} & \multicolumn{2}{|c|}{ Panicle initiation } & \multirow{2}{*}{$\begin{array}{c}C D \\
(p=0.05)\end{array}$} & \multicolumn{2}{|c|}{ Harvest } & \multirow{2}{*}{$\begin{array}{c}C D \\
(p=0.05)\end{array}$} \\
\hline & $A R$ & $\mathrm{FR}$ & & $A R$ & $\mathrm{FR}$ & & $A R$ & $\mathrm{FR}$ & \\
\hline OC (\%) & 1.18 & 1.08 & 0.08 & 0.97 & 1.05 & 0.07 & 0.85 & 0.93 & 0.08 \\
\hline $\mathrm{P}\left(\mathrm{kg} \mathrm{ha}^{-1}\right)$ & 13.03 & 19.10 & 1.25 & 11.99 & 16.16 & 2.73 & 19.05 & 13.29 & 6.90 \\
\hline $\mathrm{K}\left(\mathrm{kg} \mathrm{ha}^{-1}\right)$ & 132.40 & 65.29 & 7.97 & 127.30 & 62.59 & 8.64 & 109.48 & 48.37 & 2.07 \\
\hline $\mathrm{Ca}\left(\mathrm{mg} \mathrm{kg}^{-1}\right)$ & 188.96 & 257.64 & 35.21 & 176.68 & 189.81 & 6.42 & 167.76 & 147.83 & 14.09 \\
\hline $\mathrm{Mg}\left(\mathrm{mg} \mathrm{kg}^{-1}\right)$ & 10.75 & 9.63 & 1.02 & 11.29 & 8.32 & NS & 10.21 & 7.48 & NS \\
\hline $\mathrm{S}\left(\mathrm{mg} \mathrm{kg}^{-1}\right)$ & 21.61 & 25.21 & 2.83 & 20.58 & 28.66 & 4.26 & 18.89 & 21.50 & NS \\
\hline $\mathrm{Fe}\left(\mathrm{mg} \mathrm{kg}^{-1}\right)$ & 51.65 & 115.84 & 4.56 & 48.63 & 100.45 & 9.55 & 48.50 & 84.58 & 7.27 \\
\hline $\mathrm{Mn}\left(\mathrm{mg} \mathrm{kg}^{-1}\right)$ & 23.66 & 12.10 & 2.26 & 19.90 & 9.30 & 1.53 & 19.98 & 10.57 & 0.74 \\
\hline $\mathrm{Zn}\left(\mathrm{mg} \mathrm{kg}^{-1}\right)$ & 0.875 & 2.35 & 0.72 & 0.95 & 1.29 & 0.16 & 0.66 & 1.18 & 0.24 \\
\hline $\mathrm{Cu}\left(\mathrm{mg} \mathrm{kg}^{-1}\right)$ & 6.46 & 4.58 & 0.36 & 5.96 & 3.31 & 0.23 & 3.78 & 3.30 & 0.61 \\
\hline $\mathrm{B}\left(\mathrm{mg} \mathrm{kg}^{-1}\right)$ & 0.35 & 0.47 & 0.01 & 0.37 & 0.49 & 0.07 & 0.33 & 0.47 & 0.045 \\
\hline
\end{tabular}




\begin{tabular}{|c|c|c|c|c|c|c|c|c|c|c|c|c|}
\hline \multirow[t]{2}{*}{ Parameters } & \multicolumn{2}{|c|}{ Active tillering } & \multirow[t]{2}{*}{$C D$} & \multicolumn{2}{|c|}{ Panicle initiation } & \multirow[t]{2}{*}{$C D$} & \multicolumn{2}{|c|}{ Harvest Straw } & \multirow[t]{2}{*}{$C D$} & \multicolumn{2}{|l|}{ Grain } & \multirow[t]{2}{*}{$C D$} \\
\hline & AR & $\mathrm{FR}$ & & $A R$ & $\mathrm{FR}$ & & $A R$ & $\mathrm{FR}$ & & $A R$ & FR & \\
\hline N (\%) & 2.49 & 2.36 & 0.10 & 2.89 & 2.20 & 0.17 & 0.56 & 0.47 & 0.03 & 0.44 & 0.42 & NS \\
\hline$P\left(\mathrm{~kg} \mathrm{ha}^{-1}\right)$ & 0.28 & 0.30 & 0.019 & 0.24 & 0.27 & 0.02 & 0.19 & 0.18 & .024 & 0.27 & 0.28 & NS \\
\hline $\mathrm{K}\left(\mathrm{kg} \mathrm{ha}^{-1}\right)$ & 2.14 & 1.97 & 0.13 & 2.64 & 2.24 & 0.21 & 1.12 & 1.03 & 0.04 & 0.26 & 0.23 & 0.015 \\
\hline $\mathrm{Ca}\left(\mathrm{mg} \mathrm{kg}^{-1}\right)$ & 903.5 & 943.96 & 38.25 & 970.83 & 997.04 & 25.08 & 775.07 & 1064.35 & 34.87 & 138.16 & 183.73 & 17.84 \\
\hline $\mathrm{Mg}\left(\mathrm{mg} \mathrm{kg}^{-1}\right)$ & 427.09 & 411.31 & 14.08 & 420.25 & 395.61 & 11.01 & 409.21 & 381.69 & 18.63 & 152.25 & 141.06 & NS \\
\hline $\mathrm{S}\left(\mathrm{mg} \mathrm{kg}^{-1}\right)$ & 771.45 & 807.75 & 28.21 & 769.35 & 816.88 & 26.24 & 669.48 & 710.63 & 25.36 & 658.93 & 722.13 & 29.16 \\
\hline $\mathrm{Fe}\left(\mathrm{mg} \mathrm{kg}^{-1}\right)$ & 1013.96 & 1199.33 & 39.28 & 903.35 & 949.54 & 26.94 & 487.88 & 840.12 & NS & 195.93 & 320.59 & 16.24 \\
\hline $\mathrm{Mn}\left(\mathrm{mg} \mathrm{kg}^{-1}\right)$ & 167.86 & 276.17 & 10.93 & 146.93 & 184.25 & 17.11 & 101.81 & 155.91 & 15.98 & 82.99 & 97.98 & 13.66 \\
\hline $\mathrm{Zn}\left(\mathrm{mg} \mathrm{kg}^{-1}\right)$ & 50.15 & 44.67 & 4.98 & 66.92 & 38.70 & 10.21 & 29.62 & 26.03 & NS & 7.62 & 5.76 & 0.89 \\
\hline $\mathrm{Cu}\left(\mathrm{mg} \mathrm{kg}^{-1}\right)$ & 3.12 & 3.40 & 0.15 & 2.33 & 2.93 & 0.24 & 2.16 & 2.99 & 0.21 & 3.06 & 2.34 & 0.66 \\
\hline $\mathrm{B}\left(\mathrm{mg} \mathrm{kg}^{-1}\right)$ & 3.77 & 4.55 & 0.38 & 5.15 & 6.67 & 0.41 & 4.52 & 8.76 & 1.21 & 5.76 & 7.62 & 0.87 \\
\hline
\end{tabular}

$\mathrm{CD}: \mathrm{CD}(p=0.05)$

reversion of applied soluble $\mathrm{P}$ (as the in situ $\mathrm{pH}$ increased to 8) to tri calcium phosphate as a result of increased Ca due to application of larger quantity of lime. This is evidenced from the fact that there was a reduction in available $\mathrm{Ca}$ status from $315.15 \mathrm{mg} \mathrm{kg}^{-1}$ at active tillering to $290.81 \mathrm{mg}$ $\mathrm{kg}^{-1}$ at panicle initiation, with an increase in Ca bound $\mathrm{P}$ from a distribution of $16.3 \%$ at active tillering to $18.1 \%$ at $\mathrm{PI}$. Further, at harvest, available $\mathrm{P}$ increased in this system. The precipitated phosphorus as insoluble tri calcium phosphate (with excess quantity of lime-8.5 $\mathrm{t} \mathrm{ha}^{-1}$ ) might have solubilized as time progresses through the total growing season slowly, which in turn resulted in an increase in available $\mathrm{P}$ status in lime treatment as per SMP buffer method..

The available $P$ status was found highest under flooded system of rice cultivation except at harvest (Table 2). The increased solubility of Fe and $\mathrm{Mn}$ under submergence, released the corresponding bound $\mathrm{P}$ to the soil solution (Saharawat, 2005). This resulted in highest available $P$ under flooded system at active tillering and at panicle initiation. Corresponding increase in $\mathrm{P}$ content in plant was also observed (Table 3 ). But at harvest, the applied $\mathrm{P}$ precipitated as insoluble calcium phosphate lead to decreased $\mathrm{P}$ availability. The increase in $\mathrm{N}$ absorption and decrease in $\mathrm{P}$ absorption under aerobic system was reported by Kato et al. (2013).

Under both the systems, the increase in available $\mathrm{K}$ was in accordance with the initial value. The available $K$ status was highest under aerobic condition throughout the crop growth because of reduced rate of leaching under this environment (Table 2). Highest $\mathrm{K}$ content in plant was also recorded under aerobic rice system (Table 3 ).

\subsection{Secondary nutrients}

The highest available $\mathrm{Ca}$ at active tillering and panicle initiation was recorded in flooded system of rice cultivation (Table
2). This was due to applied lime which became available by solubilization. At harvest, the available Ca became precipitated as insoluble calcium phosphate which decreased the availability of both $\mathrm{Ca}$ and $\mathrm{P}$ under flooded condition. Under aerobic condition, the available Ca was increased, but the rate of increase was less when compared with that of flooded condition, because of the precipitation of applied lime (especially in treatment as per SMP buffer method) with applied $\mathrm{P}$ as insoluble Ca phosphate. Further, at harvest this precipitated calcium phosphate must have solubilized to mono calcium phosphate, which resulted in increase of available $\mathrm{Ca}$ and available $\mathrm{P}$ at this stage. The highest $\mathrm{Ca}$ content in plant was recorded under flooded system throughout the crop growth even though applied lime was more under aerobic condition (Table 3). This was because of the better solubility of applied lime under flooded system by the conversion of applied lime as $\mathrm{CaO}$ to $\mathrm{Ca}(\mathrm{OH})_{2}$.

Comparatively higher available $\mathrm{Mg}$ was recorded under aerobic system (Table 2), though the initial status was lower than flooded system because of reduced rate of leaching losses. This was reflected in $\mathrm{Mg}$ content in plant also (Table 3).

The available sulphur status recorded was the highest under flooded condition (Table 2). Application of lime as per SMP buffer method increased the available $\mathrm{S}$ status under both systems of rice cultivation due to effect of lime on organic manure decomposition and mineralization of sulphur. This was reflected in sulphur content in plant also (Table 3).

\subsection{Available iron status and iron toxicity management}

The initial status of available Fe was $56.78 \mathrm{mg} \mathrm{kg}^{-1}$ and 113.74 $\mathrm{mg} \mathrm{kg}^{-1}$ under aerobic and flooded conditions respectively (Table 1). Under flooded environment, the status of available Fe was higher because of the reduction of $\mathrm{Fe}^{3+}$ to $\mathrm{Fe}^{2+}$ (Table 2). The available Fe status was found decreased under aerobic 
condition due to oxidation of $\mathrm{Fe}^{2+}$ to insoluble $\mathrm{Fe}^{3+}$ (Figure 3). However under both systems of rice cultivation, the available Fe status was decreased with increase in dose of lime because of precipitation of oxides and hydroxides of iron at near neutral $\mathrm{pH}$. Highest Fe content in plant was recorded under flooded system of rice cultivation (Table 3 ).

Comparison between aerobic and flooded systems

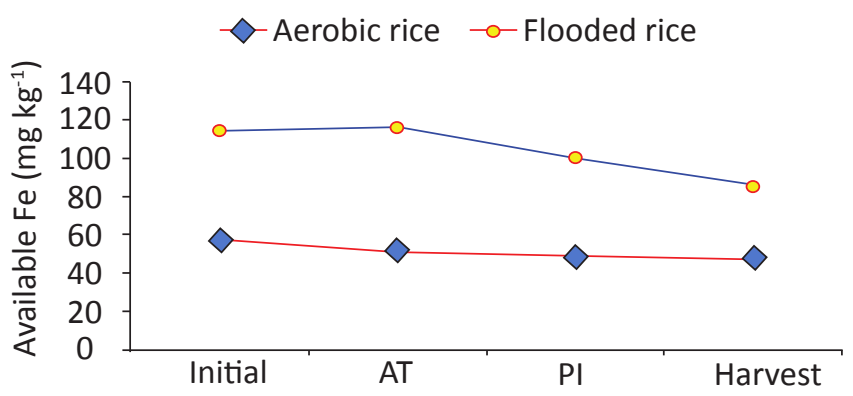

Effect of lime on available Fe $\left(\mathrm{mg} \mathrm{kg}^{-1}\right)$ $\neg-$ Lime (POP) aerobic rice - - Lime $(\Delta \mathrm{pH})$ aerobic rice $\neg$-Lime (SMP) aerobic rice $-\mathbb{Z}$-Lime (POP) flooded rice

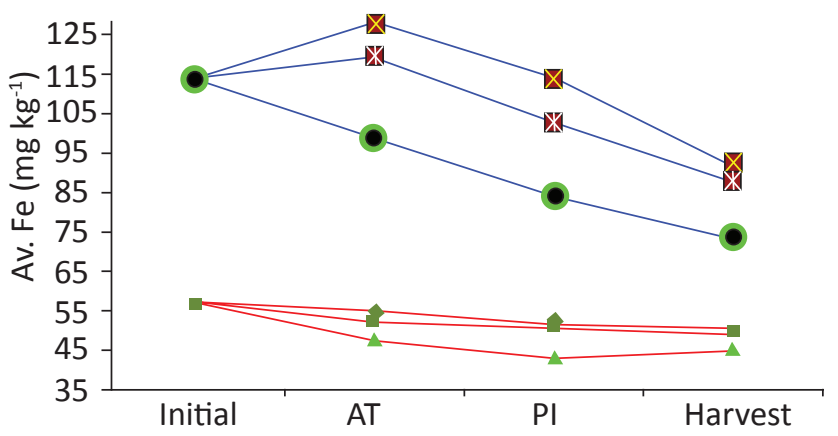

Figure 3: Changes in available Fe status under aerobic and flooded systems

Iron toxicity is a severe problem for rice due to high acidity and Fe content in lateritic acidic soils of Kerala. The solubility of $\mathrm{Fe}$ increases with flooding due to reduction from ferric to ferrous forms. The increased concentration of Fe in soil solution adversely affected the absorption of $\mathrm{K}$ (Neue et al., 1998), Mg and $\mathrm{Zn}$ under flooded system in all stages of sampling. Further the $\mathrm{Fe}^{2+}$, formed in situ in the soil found precipitated $\left(\mathrm{as} \mathrm{Fe}^{3+}\right)$ in the rice roots by root oxidation. For root respiration, molecular oxygen was channelled from the atmosphere through the stems to the roots through the aerenchyma tissue (Becker and Asch, 2005). This aerenchyma was found developed upon the establishment of anoxic conditions, only under flooded system. The rice root develops aerenchyma (air spaces formed by programmed cell death in the cortex layer to improve oxygen transport) to a lesser extent under aerobic conditions (Henry et al., 2012).

\subsection{Other micronutrient status in soil and plant}

The available $\mathrm{Mn}$ status under flooded environment recorded lower, when compared to that under aerobic condition. This could be in connection with the initial status, which was less under flooded system. Further, the increased availability of $\mathrm{Mn}$ due to reduction under submergence resulted in more absorption by the plant depleting its level in soil.

The lowest available $\mathrm{Zn}$ was recorded under aerobic condition (Table 2). The increased absorption of $\mathrm{Zn}$ (Table 3 ) by the crop under aerobic condition also resulted in recording lower available $\mathrm{Zn}$ in this system. On acid soils, Fe toxicity together with $\mathrm{Zn}$ deficiency is considered as one of the most important constraints to rice production, andit is the most commonly observed micronutrient disorder in wetland rice (Neueet al., 1998).Precipitation of cations such as $\mathrm{Fe}^{3+}$ and $\mathrm{Mn}^{4+}$ under aerobic system, due to increased $\mathrm{pH}$, lead todecreased competition for absorption of $\mathrm{Zn}$.

The available Cu status was almost similar under both systems of rice cultivation. Similar results were observed in case of plant content also.

The available boron status and boron content in plant was high under flooded condition because of the enhanced solubility of applied borax (soluble source of boron) and its absorption by the plant. Lime applied as per SMP buffer method decreased the available boron due to precipitation of $B$ with lime at higher $\mathrm{pH}$. The boron content in plant increased in treatments where fertilizers added based on soil test under both systems of rice cultivation, due to applied boron.

\subsection{Yield and yield attributes}

The number of tillers per hill was significantly higher under aerobic system both at AT and at PI stages than that under flooded system (Table 4). Significantly higher root CEC under aerobic environment could be attributed to more negative sites on the roots under aerobic environment (Table 4). Under flooded system the ferrous ion $\left(\mathrm{Fe}^{2+}\right)$ which is soluble, got mobilized towards the root surface where it was oxidized in presence of oxygen from the aerenchymatic tissues and got deposited as a coating thereby physically blocking the ion absorption. Under aerobic environment the iron was already in the oxidized insoluble form and hence its mobility towards the roots was restricted there by opening more sites for ion exchange.

Aslightly higher apparent free space under aerobic environment

\begin{tabular}{|c|c|c|c|c|c|c|c|c|c|c|c|c|}
\hline \multirow[t]{2}{*}{ Parameters } & \multicolumn{2}{|c|}{$\begin{array}{l}\text { Fresh root CEC } \\
\left(\mathrm{mol}(+\mathrm{kg})^{-1}\right)\end{array}$} & \multicolumn{2}{|c|}{$\begin{array}{l}\text { Apparent free } \\
\text { space } \mathrm{cm}^{3} \mathrm{~g}^{-1}\end{array}$} & \multicolumn{2}{|c|}{ No of tillers hill ${ }^{-1}$} & \multicolumn{2}{|c|}{ Panicles hill ${ }^{-1}$} & \multicolumn{2}{|c|}{$\begin{array}{l}\text { grain yield } \\
\left(\mathrm{t} \mathrm{ha}^{-1}\right)\end{array}$} & \multicolumn{2}{|c|}{$\begin{array}{l}\text { Straw yield } \\
\left(\mathrm{t} \mathrm{ha}^{-1}\right)\end{array}$} \\
\hline & AR & FR & AR & FR & AR & $\mathrm{FR}$ & AR & $F R$ & AR & $F R$ & AR & FR \\
\hline Mean & 1.67 & 1.06 & 3.57 & 3.32 & 14.02 & 10.1 & 11.96 & 8.83 & 6.23 & 5.12 & 6.40 & 5.52 \\
\hline $\mathrm{CD}(p=0.05)$ & \multicolumn{2}{|c|}{0.53} & \multicolumn{2}{|c|}{0.21} & \multicolumn{2}{|c|}{3.15} & \multicolumn{2}{|c|}{3.15} & \multicolumn{2}{|c|}{0.41} & \multicolumn{2}{|c|}{0.21} \\
\hline
\end{tabular}


also supports this argument. Aerobic environment enhanced root and shoot growth when compared to flooded system (Table 5). This might have contributed to more uptake of nutrients and to yield under aerobic system. Higher deep root in aerobic culture than in flooded culture was also observed by Kato and Okami (2010).

Table 5: Shoot mass, root mass and root volume under aerobic and flooded systems

\begin{tabular}{lcccc}
\hline $\begin{array}{l}\text { Growing con- } \\
\text { dition }\end{array}$ & $\begin{array}{c}\text { Shoot } \\
\text { mass }\end{array}$ & $\begin{array}{c}\text { Root } \\
\text { mass }\end{array}$ & $\begin{array}{c}\text { Root vol- } \\
\text { ume }\end{array}$ & $\begin{array}{c}\text { Root } \\
\text { length }\end{array}$ \\
\hline Aerobic rice & $210.97 \mathrm{~g}$ & $18.6 \mathrm{~g}$ & $30 \mathrm{~cm}^{3}$ & $55 \mathrm{~cm}$ \\
\hline Flooded rice & $172.61 \mathrm{~g}$ & $13.9 \mathrm{~g}$ & $23.5 \mathrm{~cm}^{3}$ & $29 \mathrm{~cm}$
\end{tabular}

\subsection{Water requirement of the crop}

The water requirement of the crop under both systems was calculated for the crop duration of 94 days, from transplanting one week prior to harvest of the crop. Under flooded system, $5 \mathrm{~cm}$ of standing water was maintained in the field throughout the crop growth. Under aerobic system $4 \mathrm{~cm}$ irrigation (800I $\mathrm{m}^{2}$ ) was given on alternate days. A reduction of $57 \%$ in water requirement was recorded for rice under aerobic condition (Table 6).

\begin{tabular}{lcccccc}
\hline \multicolumn{6}{l}{ Table 6: Total water requirement by the crop } \\
\hline SRC & DI & DI $^{*}$ & NDI & TWR & $\begin{array}{l}\text { Yield } \\
(\mathrm{kg})\end{array}$ & WRPR \\
\hline $\begin{array}{l}\text { Aerobic } \\
\text { rice }\end{array}$ & $4 \mathrm{~cm}$ & $\begin{array}{l}\text { Once in } \\
\text { two days }\end{array}$ & 47 & $18.8 \times 10^{6}$ & 6230 & 3018 \\
\hline $\begin{array}{l}\text { Flood- } \\
\text { ed rice }\end{array}$ & $5 \mathrm{~cm}$ & Daily & 87 & $43.5 \times 10^{6}$ & 5120 & 8497 \\
\hline
\end{tabular}

SRC: System of rice cultivation; DI: Depth of irrigation; $\mathrm{DI}^{*}$ : Duration of irrigation; NDI: No of days of irrigations; TWR: Total water requirement (L); WRPR: Water requirement to produce $1 \mathrm{~kg}$ rice $(\mathrm{L})$

\section{Conclusion}

Ultimately under aerobic system, increased and balanced absorption of potassium, calcium, magnesium, and zinc with effective management of nutritional stress induced by toxic levels of Fe could be achieved. Hence aerobic rice recorded the highest grain and straw yield $\left(6.23 \mathrm{t} \mathrm{ha}^{-1}\right.$ and $6.35 \mathrm{t} \mathrm{ha}^{-1}$ respectively) than that under flooded system (5.12 $\mathrm{t} \mathrm{ha}^{-1}$ and $5.52 \mathrm{t} \mathrm{ha}^{-1}$ respectively).

\section{References}

Becker, M., Asch, F., 2005. Iron toxicity in rice, conditions and management concepts. Journal of Plant Nutrition and Soil Science 168, 558-573.

Beena, V. I., Thmpatti, K.C.M., 2013. Characterization of Acidity in Acid Sulphate Soils of Kerala. Journal of Life Sciences 7(8), 907-912.

Cheng, Y.Q., Yang, L.Z., Cao, Z.H., Ci, E., Yin, S., 2009.
Chronosequential changes of selected pedogenic properties in paddy soils as compared with non-paddy soils. Geoderma. 151, 31-41.

Fageria, N.K., Baligar, V.C., 2008. Ameliorating soil acidity of tropical Oxisols by liming for sustainable crop production.Advances in Agronomy 99, 345-399.

Fageria, N.K., Baligar, V.C., Li, Y.C., 2008b. The role of nutrient efficient plants in improving crop yields in the twenty first century. Journal of Plant Nutrition 31, 1121-1157

Fageria, N.K..Carvalho, G.D. Santos, A.B Ferreira, E.P.B., Knupp, A.M., 2011. Chemistry of Lowland Rice Soils and Nutrient Availability, Communications in Soil Science and Plant Analysis, 42, 16, 1913-1933.

Fageria, N.K., Santos, A.B., Barbosa Filho, M.P., Guimaraes, C.M., 2008a. Iron Toxicity in Lowland Rice, Journal of Plant Nutrition 31(9), 1676-1697.

Fageria, N.K., Slaton, N.A., Baligar, V.C., 2003. Nutrient management for improving lowland rice productivity and sustainability. Advances in Agronomy 80, 63-152.

Geetha, P., Sureshkumar, P., 2016. Dynamics and availability of Iron in acid lateritic soil (Ultisol) to rice as influenced by water regime and liming.Advances In life Sciences 5(16), 6318-6333.

Henry, A., Cal, A.J., Batoto, T.C., Torres, R.O., Serraj, R., 2012. Root attributes affecting water uptake of rice (Oryza sativa) underdrought. Journal of Experimental Botany 63, 4751-4763.

Kato, Y., Okami, M., 2010. Root growth dynamics and stomatal behaviour of rice (Oryza sativa L.) grown under aerobic and flooded conditions. Field Crops Research 117, 9-17.

Kato, Y., Tajima, R., Homma, K., Toriumi, A., Yamagishi, J., Shiraiwa, T., Mewatanakarm, P., Jongdee, B., 2013. Root growth response of rainfed lowland rice to aerobic conditions in northeastern Thailand. Plant and Soil 368, 557-567.

Mahabub, H., Narciso, J., 2004. Global rice economy: Long term perspectives. In proceedings of the FAO rice conference-Rice in global markets-Rome, 04/CRS. Rome, Italy.

Neue, H.U., Quijano, C., Senadhira, D.,Setter, T., 1998. Strategies for dealing withmicronutrient disorders and salinity in lowland rice systems. Field Crop Research 56, 139-155.

Panse, V.G., Sukhatme, P.V., 1978. Statistical Methods for Agricultural Workers. Indian Council of Agricultural Research, New Delhi, India.

Rout, G.R., Sahoo, S., 2015. Role of iron in plant growth and metabolism. Reviews in Agricultural Science 3, 1-24.

Sahrawat, K.L., 2005. Iron toxicity in wetland rice and the role of other nutrients. Journal of Plant Nutrition 27(8), 1471-1504.

Saharawat, K.L., 2012. Soil fertility in flooded and non-flooded irrigated rice systems. Archives of Agronomy and Soil Science 58(4), 423-436, DOI: 10.1080/03650340.2010.522993.

Zuo, Y., Zhang, F., 2011. Soil and crop management strategies to prevent iron deficiency in crops. Plant and Soil 339, 83-95. 